\title{
SALAFI DAKWAH AND THE DISSEMINATION OF ISLAMIC PURITANISM IN INDONESIA: A CASE STUDY OF THE RADIO OF RODJA ${ }^{1}$
}

\section{Ayang Utriza Yakin}

Research Institute of 'Religions, Spiritualities, Cultures, Societies' (RSCS), Université Catholique de Louvain (UCLouvain), Louvain-la-Neuve, Belgium.

Email: ayang.walad@uclouvain.be

\begin{abstract}
The article examines Islamic proselytization (dakwah) on Rodja Radio by Salafi preachers (dai). The radio program targets not only Salafis but also non-Salafi Muslims in general. It seeks to analyze the content of dakwah aired by Radio Rodja 756 AM., the leading Salafi radio station located in Cileungsi, Bogor, West Java. This article focuses mainly on current legal, social, and political issues of the Salafi dakwah. The dakwah aired by Rodja Radio intends to encourage the Muslim ummah to return to the way of life that strictly follows the tradition of the Prophet Muhammad and the first three generations of Muslims. The Salafi radio station propagates Islamic puritanism that in many ways contradicts modern values. Rodja Radio preachers demonstrate their reluctance to embrace modern ideas, such as democracy, human rights, w omen's rights, and to some extent, art and education. This article reveals that the radio serves as a public sphere where the Salafis disseminate 'Islamic Puritanism' on Indonesian air.
\end{abstract}

Keywords: Salafi, Rodja Radio, Puritanism, Indonesian Islam, Modernism.

DOI: http://dx.doi.org/10.20414/ujis.v22i2.335

${ }^{1}$ This article is originally based on my research report funded by the Saiful Mujani Research and Consulting (SMRC). The first draft was presented in the Asia Leadership Fellow Program (ALFP), Tokyo, Japan, on $7^{\text {th }}$ September 2016. I sincerely thank Din Wahid, Ali Munhanif, Dadi Darmadi, Kevin W. Fogg, and Alejandro Perez for their comments on the early draft and three anonymous reviewers for their critics, comments, and suggestions. However, I am sole responsible for any mistakes found in this piece. 


\section{Introduction}

RESEARCH ON THE INFLUENCE of religious broadcasting on Indonesian society has flourished in recent years. ${ }^{2}$ However, little research has been conducted specifically on Salafi ${ }^{3}$ radio stations and the programs and the discourse of Islamic propagation that they broadcast. Discussion on some aspects of the Salafi radio is found in Din Wahid's PhD dissertation, which he defended at Utrecht University in 2014. ${ }^{4}$ A special work on the Salafi radio was conducted by Sunarwoto, who wrote a PhD dissertation entitled "Contesting religious authority: A study on Dakwah Radio in Surakarta, Indonesia." 5 He later authored an article entitled "Salafi Dakwah Radio: A Contest for Religious Authority," ${ }^{6}$ which focused on the Salafi radio stations in Solo, such as Suara Quran, Al-Madinah,

${ }^{2}$ To mention some works on television and dakwah: James B. Hoasterey, James B. Hoasterey, Rebranding Islam: Piety, Properity, and a Self-Help Guru (Standford: Standford University Press, 2015); Dicky Sofjan and Mega Hidayati, Religion and Television in Indonesia: Ethics Surrounding Dakwahtainment (Geneva: Globethics.net, 2013); Julia Day Howell, "Modulations of Active Piety: Professors and Televangelists as Promoters of Indonesian 'Sufisme,'" in Expressing Islam: Religious Life and Politics in Indonesia, ed. Greg Fealy and Sally White (Singapore: ISEAS Publishing, 2008), 40-62.

${ }^{3}$ In this article, I use the term 'Salafi' and 'Salafi-Wahhabi' interchangeably in the context of Rodja Ra dio and its discussion at Indonesian Islam's setting. For a brief introduction to Sala fism, see Joas Wagemakers, "Sala fism," Oxford Research Encyclopedia of Religion (August 5, 2016), accessed March 19, 2018, http://oxfordre.com/view/10.1093/acrefore/9780199340378.001.0001/acrefore9780199340378-e-255.

${ }^{4}$ Din Wahid, "Nurturing the Salafi Manhaj: A Study of Three Salafi Pesantrens in Contemporary Indonesia" (PhD Thesis, Utrech University, 2014); see, for example p. 103.

${ }^{5}$ Sunarwoto, "Contesting Religious Authority: A Study on Dakwah Radio in Surakarta, Indonesia" (Doctoral Thesis, Tilburg University, 2015) Sunarwoto's dissertation focuses not only on the content of the dakwah propagated on the radio stations but also on the networks, preachers, funding, and internal conflicts among the Salafis themselves. He wrote especially on the debate about religious authority through radio.

6 Sunarwoto, "Salafi Dakwah Radio: A Contest for Religious Authority," Archipel. Études interdisciplinaires sur le monde insulindien, no. 91 (May 15, 2016): 203-230, accessed December 21，2018, http://journals.openedition.org/ archipe1/314. 
and Darussalaf. In these works, he emphasized his inquiry on religious authority.

Three other publications have discussed Rodja Radio. First, Siti Aminah wrote an MA thesis entitled "Strategi Informasi Konvergensi Media: Studi Kasus Radio Rodja 756 AM, Cileungsi, Bogor," which focused on the change in the radio frequency from the communication technology approach. ${ }^{7}$ Second, Adeni authored an MA thesis entitled "Institusi Televisi Keislaman: Studi atas Rodja TV sebagai Media Islam Salafi," 8 which focused primarily on Rodja Television. Third, the Centre for the Study of Islam and Society of State Islamic University (Universitas Islam Negeri/UIN) of Jakarta undertook research on the salafi radios around Indonesia, with one chapter focused on Rodja Radio entitled "Rodja: Rujukan Radio Salafi di Indonesia," 9 which provided a general description of Rodja Radio. Based on this information, no study has focused on the discourse of dakwah of Rodja Radio. Accordingly, it is critically important to study the content of the salafi dakwah on Rodja Radio.

My question in this essay is how do Rodja Salafi's preachers respond during the "question-answer" (tanya-jawab) sessions following Islamic religious teaching (pengajian) to such contemporary issues as LGBT, Islamic penal law, education and technology, and women's rights? Their answers illustrate how they interpret Muslim life in the modern era and what solutions they offer to a wide variety of the factors behind those issues. The study thus aims to describe the content of the salafi dakwah that is broadcasted by Rodja Radio. I argue that the salafi radio propagates an Islamic puritanical way of life that challenges the values and principles of modern society. The idea of a 'rejection to the modern ideas and values' is, of course, not peculiar to Muslims since this is found in other religious traditions. I show that the

7 Siti Aminah, “Strategi Informasi Konvergensi Media: Studi Kasus Radio Rodja 756 AM, Cileungsi, Bogor" (Master Thesis, Universitas Isla m Negeri Syarif Hidayatullah, 2014).

8 Adeni, “Institusi Televisi Keislaman: Studi atas Rodja TV sebagai Media Islam Salafi" (MasterThesis, Universitas Islam NegeriSyarif Hidayatullah, 2016).

${ }_{9}$ This chapter can be found in the book edited by Din Wahid and Jamhari Makruf, eds., Suara Salafisme Radio Dakwah di Indonesia (Jakarta: Kencana, 2017). 
preachers of Rodja Radio preachers are reluctant to embrace modern ideas. They reject and criticize democracy, human rights, women's rights, art and education. This article reveals that the radio serves as a medium through which the salafi spread 'Islamic Puritanism' and "Isla m as a Transnational Public Space," to borrow a phrase coined by John Bowen, ${ }^{10}$ in Indonesia and beyond.

\section{Salafism, Islamic Puritanism, and the Public Sphere}

I was unaware of the religious affiliation of Rodja Radio until attentively listening to its programs in 2015-2016, which clearly revealed their Islamic salafi ideology. Salafism ${ }^{11}$ is the Islamic ideology held by a Muslim community or group that attempt to revive the Sunnah/Tradition of the Prophet Muhammad and revitalize the way of life of the first three Muslim generations in the modern era. ${ }^{12}$ According to Henri Lauziere, there are two types of Salafism: first is Modernist Salafism. This refers to "a multifaceted movement of Islamic modernism that took shape in the late nineteenth century and lasted until the mid-twentieth century" with its 'founding fathers' Jamaluddin al-Afghani, Muhammad Abduh, and Muhammad Rashid Rị̣a. The modernist Salafism aims "to reconcile Islam to social, political, and

10 John R. Bowen, “Beyond Migration: Islam as a Transnational Public Space," Journal of Ethnic and Migration Studies 30, no. 5 (September 1, 2004): 879894, https://doi.org/10.1080/1369183042000245598.

${ }_{11}$ There is a growing literature on Salafism; see, for instance: Bernard Rougier, Qu'est-Ce Que Le Salafisme? (Paris: Presses Universitaires de France, n.d.); Meijer Roel, ed., Global Salafism: Islam's New Religious Movement (London: Hurst, 2009); Laurent Bonnefoy, Salafism in Yemen: Transnationalism and Religious Identity (London: Hurst, 2011); Frazer Egerton, Jihad in the West: The Rise of Militant Salafism (Cambridge: Cambridge University Press, 2011); Richard Gauvain, Salafi Ritual Purity: In the Presence of God (London: Routledge, 2013); Zoltan Pall, Lebanese Salafis between the Gulf and Europe: Development, Fractionalization and Transnational Networks of Salafism in Lebanon (Amsterdam: Amsterdam University Press, 2013), https://www.jstor.org/stable/j.ctt46n0kn; Zoltan Pall, Kuwaiti Salafism and Its Growing Influence in the Levant (Washington: Carnegie Endowment for International Peace, 2014), JSTOR, https://www.jstor.org/stable/resrep12899; Zoltan Pall, Salafism in Lebanon: Local and Transnational Movements (Cambridge: Cambridge University Press, 2018).

12 This is based on an interview with Dian Sudiana Fawwa z on Wednesday 29 June 2016 and Ustadz Muhammad Ihsan on Thursday 29 July 2016. 
intellectual ideals to Modernism and to rearticulate Islam to the contemporary realities and to the rational minds." 13 The second is Purist Salafism, which refers to "the most authentic and purist religious orientation within Sunni-Islam" comprising those who claim "to follow the only true Islam that can lead to the salvation."14 Purist Salafism rejects all form of innovation (bid'a), deviation (inhirāf), accretion (ziyada), speculative theology ('ilm kalam), and philosophy. Lauziere has rightly pointed out that Purist Salafism is "not compromised with potential impurities from all aspects in the religion, misguided beliefs and actions including its epistemology, and denies the validity of any intuitive or esoteric knowledge. They put the supremacy and primacy of scriptural (naql) over rational proofs ('aql)."15 Lauziere identified this as Purist Salafism and even used the term "purist" "to convey the persistent preoccupation of today's Salafi with religious purity". ${ }^{16}$

Salafism is here conceived of as Islamic puritanism. ${ }^{17}$ It should be noted that, when the term "puritanism" is used here, it does not replicate or follow literally the history of the Christian puritans in Europe. According to The New Oxford Dictionary of English, the terms "puritan" and "puritanism" were firstly used to refer to "The beliefs or principles of a group of English Protestants of the late 16 th and 17 th centuries who regarded the Reformation of the Church under Elizabeth I as incomplete and sought to simplify and regulate forms of worship." 18 In brief, puritanism can be

13 Henri Lauziere, The Making of Salafism: Islamic Reform in the Twentieth Century (New York: Columbia University Press, 2016), 5.

14 Ibid., 6.

${ }^{15}$ Ibid., 8.

16 Ibid., 6.

17 See Adis Duderija on how to understand the concept of Salafism in Traditional Sunni Islam in order to create a counter-narrative used by ISIS, Alqaeda and the like, see: Adis Duderija, "The Regress of Knowledge: Understanding the Concept of Salafism in Traditional Sunnism," ABC Religion $\mathcal{E}$ Ethics, last modified January 12, 2017, https://www.abc.net.au/religion/the regress-of-knowledge-understanding-the-concept-of-sala fism-i/10096166.

18 See the entries on "puritan" and "puritanism" in J A Simpson and E S C Weiner, New Oxford Dictionary of English (Oxford: Oxford University Press, 1998), and online version "Puritan," Oxford Dictionaries, accessed June 19, 2018, 
understood as purification movements and an appeal and a call to return to the pure teaching of religion. The dakwah broadcast by Rodja Radio represents exactly what Lauziere has explained about salafism. In other words, Salafism is far more suited to being identified with Islamic puritanism than the other categories.

This labeling is corroborated by Khaled Abou El Fadl, who considers Salafi-Wahabi as Muslim Puritans or the Puritans of Islam. ${ }^{19}$ According to him, there exist two categories of Muslim: Muslim moderates and Muslim puritans, both of whom believe that their beliefs are based on the Qur'an and the authentic tradition of the Prophet Muhammad. ${ }^{20}$ Muslim moderates describe aptly the religious convictions of the majority of Muslims. In fact, the Qur'an enjoins Muslims to be moderate as stated in Sura alBaqara 143 "And thus we have made you a just community". The Prophet Muhammad was always described as a moderate man who tended to avoid falling into extremes. Therefore, according to Abou El Fadl, "the word moderate has roots in the Islamic tradition and it conveys the normative disposition...that aptly describes the religious convictions of the majority of Muslims." 21 Muslims puritans are group of Muslims "with the distinguishing characteristic which is the absolutist and uncompromising nature of its beliefs." 22 In this sense, I agree even more with Abou El Fadl, who labels this group as "puritans" rather than fundamentalists, militants, extremists, radicals, fanatics, jihadists, or even simply

https://en.oxforddictionaries.com/definition/puritan; "Puritanism," Oxford Dictionaries, accessed June 19, 2018, https://en.oxforddictionaries.com/ definition/puritanism.

${ }^{19}$ Khaled Abou El Fadl, Reasoning with God: Reclaiming Shari'ah in the Modern Age (Lanham-London: Rowman \& Littlefield, 2017), 215-227. See the discussion on Wahhabi-Islam in its transformation from the revivalist movement into a global terror-maker as a consequence of the puritanical views understood by, for instance, Osame Ben Laden, in an extremely important book: Natana J. DelongBas, Wahhabi Islam: From Revival and Reform to Global Jihad (Oxford: Oxford University Press, 2004).

${ }^{20}$ Khaled Abou El Fadl, The Great Theft: Wrestling Islam from the Extremists (New York: HarperCollins, 2007), 5.

${ }^{21}$ Ibid., $16-18$.

22 Ibid., 18. 
Islamists. ${ }^{23}$ In fact, their orientation "tends to be purist, in the sense that it is intolerant of competing points of view and considers pluralist realities to be a form of contamination of the unadulterated truth." 24

Based on this explanation, the term "Islamic puritanism", used in this article, refers to a literal interpretation of the principal source of Islam (literalism) and appeal to the way of life of the Prophet and restoration of the spirit of the first three generations to what they were. It calls all Muslims to behave and live according to the standard of "glory and golden age of Islam" during the first three centuries of Early Islam. Their ideology is to purify what they consider non-compliance with religious doctrine and teaching as mentioned in the Qur'an and Sunna. They oppose what they perceive to be innovation in religious matters (bid'a) and strictly and literally follow the Prophetic tradition. Therefore, they call themselves Ahl al-Athar or Ahl al-Sunnah (followers of tradition and companion). ${ }^{25}$

It is interesting to see how effectively a public sphere is used by religious radio to propagate and disseminate a certain ideology. "The power of religion in the public sphere" 26 is used by a group of salafi using radio to disseminate their teachings and messages. The "public sphere" here refers to what the German Philosopher and Sociologist Jurgen Habermas defined as: public being "...when they are open to all in contrast to closed or exclusive affairs" and the public sphere is "a society engaged in critical public debate." 27 The public sphere is, therefore, a social space that is open to all members of society, regardless of their color, race, ethnicity, and religion, because it belongs to the public. All public arenas contribute toward creating an open and social culture by

${ }^{23}$ Ibid.

24 Ibid.

25 This definition is based on the interview with Ustadz Muhammad Ihsan on Thursday 29 July 2016.

26 I am influenced by this book: Eduardo Mendieta and Jonathan Vanantwerpen, The Power of Religion in the Public Sphere (New York: Columbia University Press, 2011).

27 Jurgen Habermas, The Structural Transformation of the Public Sphere: An Inquiry into a Category of Bourgeois Society, trans. Thomas Burger (Cambridge: The MIT Press, 1989), 1, 52. 
sharing common knowledge with others and radio is one of the public arenas. We will demonstrate that a specific group of Salafi in Indonesia has been using the public sphere for several years to diffuse their ideology across Indonesian Muslim society and beyond. The thesis in this article is that Rodja Radio has made significant efforts to "salafize" Indonesian Islam through the medium of radio.

This article is based on research that I conducted over an eight-month period. I listened to Rodja Radio broadcasts almost daily from January to June of 2016. However, I made notes on anything I merely considered interesting because of the way in which the preachers responded to the current legal, social and political issues, as requested by Rodja Radio's listeners. I interviewed Rodja Radio's preachers, managers, and its listeners. Although I amassed a lot of other information broadcasted, my focus was on the content of the dakwah. Rodja Radio is concerned with a variety of dakwah topics on Hadith and Sunnah (the Prophets' sayings/narrations and Prophetic tradition), Tafsir (Quran interpretation), Sìrah (Islamic history), Figh (Islamic law), Aqìdah and Tawhìd (theology). My intention here is not to present a fully detailed study of how Rodja Radio operates in every aspect, but to limit the discussion to the content of its dakwah.

\section{Salafi Dakwah on Rodja Radio}

To protect Indonesian society from the moral degradation caused by the infidel (kafir) Western culture, Salafis believe in the need to launch dakwah radio stations. Even though Westerners invented and developed this means of mass broadcasting, Salafis eventually allowed its use in order to preach on matters of religion, Islamic public order, and morality among their Muslim fellows. In 2004, a group of young Salafis ${ }^{28}$ from Kampung Tengah, Cileungsi, Bogor, West Java, met and decided to propagate and disseminate pure dakwah in order to 'protect' the belief (aqidah/tawhìd) of the Muslim community from bid'ah

28 This group of young Salafis comprises Abu Yahya Badrussalam, Dian Sudiana Fawwaz, Muhammad Ihsan, and Agus Hasanuddin, whom I call Rodja Radio's "founding fathers". 
(unlawful innovations in religious matters). In early 2005, they established the Rodja Radio station, based simply on the Islamic principle of 'opposing evil and enjoining good' and that 'every innovation is a misguidance and every misguidance leads to hellfire.' ${ }^{29}$

Managed by a small but creative group, in its first five years, Rodja Radio grew slowly but surely and expanded rapidly across Indonesia. Over the following five years, an innovative array of products was added. ${ }^{30}$ More than sixty-five radio stations in Indonesia rely on Rodja Radio's dakwah programs. ${ }^{31}$ Furthermore, 'influential' Salafi radio stations in Java rely on Rodja Radio and import their dakwah. ${ }^{32}$ No radio rating has been carried out regarding this Salafi radio station. However, according to www.radioguide.com, which rates (for every category) the top forty radio stations in Indonesia, Rodja Radio is one of the most listened radio stations (number 7). ${ }^{33}$ In comparison, www.korando.com listed Rodja Radio in the $77^{\text {th }}$ amongst the top one hundred radio stations in Indonesia. ${ }^{34}$ These ratings show that Rodja Radio has a place in Indonesia within the religious radio category.

There exist no reliable data on how many Indonesian Muslims listen to Rodja Radio. It has been claimed that more 100,000 people are 'faithful' listeners to Rodja Radio dakwah programs..$^{35}$ If this figure is correct, then there is no doubt that Rodja Radio is the leading Salafi radio station in Indonesia although the figure is still lower than those of other public radios. ELSHINTA, a leading news radio station, has more than 1.3 million listeners and this number has been growing since ELSHINTA has seven branches

${ }^{29}$ Rodja is an abbreviation from RadiO Dakwah ahlus sunnah wal Jamaah (Propagation Radio of the Adherents to the Sunnah and the Followers).

${ }^{30}$ Rodja operates satellite tele vision, a radio streaming satellite radio station, online radio and flexi radio, as well as an Isla mic boarding school for memorizing the Quran, an Islamic kindergarten and an Islamic integrated primary school.

${ }^{31}$ Interview with Dian Sudiana Fawwaz on Wednesday,29 June 2016.

32 Sunarwoto, “Contesting Religious Authority," see, for example, p. 243.

${ }^{33} \mathrm{http}$ ://test.radioguide.fm/indonesia/top-40? page $=1$

34 https://korananakindonesia.com/2011/11/07/100-stasiun-radio-palingfavorit-di-jakarta-versi-korando/

${ }^{35}$ Interview with Ustadz Muhammad Ihsan on Thursday 29 July 2016. 
and 31 radio stations that rely on its broadcasting in Indonesia. GEN FM, a music radio station, has more than 4.1 million listeners in Jakarta, and in the surrounding areas (Depok, Bogor, Tangerang, and Bekasi), there are 3.4 million listeners.

Accordingly, we can believe the management team of Rodja Radio's claim that its listeners number in the hundred thousand range. Moreover, the number of Rodja Radio listeners could be more than a hundred thousand because it has five branches of the Rodja Radios, in Bandung, Berau, Lampung, Tanjung Pinang, and Pontianak. In addition, 65 radio stations around Indonesia rely on its Islamic broadcasting. This number would rise if we consider Rodja Radio's streaming and satellite options. One may estimate that Rodja's Radio broadcasts might reach more than one million listeners.

Based on this information, the number of people who listen to Rodja Radio has been increasing in Indonesia although no exact data of its listener is available. Another fact is that Rodja Radio has organized several huge gatherings in the Istiqlal mosque and other large mosques, which a hundred thousand people attended. They came along to these Islamic gatherings because they listen to Rodja Radio. From this simple fact alone, it is important to discover which issues the radio station addresses in its preaching and what the impact of Rodja Radio will be on the future of Indonesia.

\section{Issues related to the Salafi Dakwah on Rodja Radio}

I and my researcher assistant randomly interviewed more than 80 people others in Jakarta and its surroundings about the content of dakwah broadcast on Rodja Radio and their reaction to it. ${ }^{36}$ The findings revealed that they are very concerned about Rodja Radio because it promotes basic Islamic teachings. I chose four issues of the dakwah contain, as they deal with the problem of the relations between Islam and the ideas of modernism, which are the central criticism of Salafism. Therefore, my discussion focuses on four major issues that arose during the live broadcast interactive

36 The interviews were conducted between February and May 2016 by almost 40 students from the Faculty of Sharia and Law, State Islamic University, Jakarta. 
programs (question and answer sessions) between the preachers and listeners. ${ }^{37}$

It should be noted that nearly all of Indonesian preachers on Rodja Radio are graduates of the Islamic University of Medina in Saudi Arabia or the Islamic University of Muhammad Ibn Saud in Jakarta (LIPIA), while a few others studied at a small number of universities in Yemen and Pakistan. ${ }^{38}$ Jajang Jahroni ${ }^{39}$ and Amanda Kovacs $^{40}$ showed that Saudi Arabia used education, through scholarship to study at LIPIA, financed school and mosque construction, and built Islamic schools, as a political strategy for maintaining its influence over Indonesia. In fact, LIPIA represents a microcosm of Saudi ideology, in which Salafi-Wahhabi norms and tradition prevail. Accordingly, it directly influences its students, who later become religious teachers and dai, as their agency is to spread Salafi-Wahhabi teachings within Indonesian society, who mostly do not follow the Salafi-Wahabism. As a result, LIPIA, as the Salafi model education, challenge moderate Indonesian Islam and instigate the growth of puritanical understanding of Islam, which lead into conservatism and even radicalism. ${ }^{41}$ Below are examples of the Salafis' Islamic discourse on the Rodja Radio.

\section{Issues on LGBT (Lesbian, Gay, Bisexual and Transsexuals)}

I found many interesting and often controversial issues. For example, when the controversies over LGBT arose in Indonesia in

37 The preachers' names will be found at the end of each of their answers.

38 Aminah, "Strategi Informasi Konvergensi Media," 106-108.

39 JajangJahroni, “The Political Economy of Knowledge: Shari ah and Saudi Scholarship in Indonesia," Journal of Indonesian Islam 7, no. 1 (June 1, 2013): 165186, accessed December 19, 2018, http://jiis.uinsby.ac.id/index.php/JIIs/ article/view/124.

40 Amanda Kovacs, "Saudi Arabia Exporting Salafi Education and Radicalizing Indonesia's Muslims," GIGA Focus International Edition English, no. 07 (2014): 7, https://www.giga-hamburg.de/en/publication/saudi-arabiaexporting-salafi-education-and-radicalizing-indone sia \%E2\%80\%99s-muslims.

41 Toto Suharto, "Transnational Islamic Education in Indonesia: An Ideological Perspective," Contemporary Islam 12, no. 2 (July 1, 2018): 101-122, https://doi.org/10.1007/s11562-017-0409-3. 


\section{March and April, 2016, I listened to many questions from listeners on the radio such as the following:}

I am very concerned with the LGBT social problem because it is a sort of contagious disease that could be transmitted especially to adolescents as they are looking for their self-identity. What is the opinion of the Ahlus Sunnah (Salafi) on the se LGBT issues? ${ }^{42}$

Ibu Lina from Jakarta

\section{The ustadh answered the question as follows:}

"Being a member of the LGBT community is without doubt a huge sin. Allah, the most glorified and the most high, narrated the story of the people of the prophet Luth and how He punished them severely. Their torment is a lesson for the people living after them. Allah, the most glorified and the most high, abhorred of this behavior and, even more, the Prophet Muhammad, peace be upon him, cursed their behavior. The prophet said 'may Allah, the most glorified and the most high, curse men who resemble women and women who resemble men'. Most ulamas (Islamic scholars) have written in their books, that being LGBT in Islam is punished by the death penalty. In fact, it is an alarming disease that could be transmitted to other people and destruct their behavior. First, this disease will destroy human life and harm social life. Imagine that men love men and women love women. The re will no births or descendants at all. Human life will become extinct in the world. Second, being an LGBT is against the primordial human nature (fitrah) that Allah, the most glorified and the most high, bestowed on human beings from the outset: men love women and vice-versa. Allah, the most glorified and the most high, did not create human beings in LGBT conditions. In nature, no humans are born as LGBT. Accordingly, LGTB should be fought against and eliminated. We can fight LGBT through violent and peaceful actions. Parents have to protect their children from LGBT. They must take care of their children's education and their social interaction. Everybody must stand toge ther against LGBT and we do not want our new generations to become extinct because of this LGBT disease. Those who support LGBT dislike religion. They dislike Allah, the most glorified and the most high, and the Prophet, peace be upon him. They are not believers (mu'min) and do not fear Allah's punishment (muttaqin). They merely live here in this world (dunya) and only follow their own desires (shahwat). We ask the government NOT to allow this contagious LGBT disease have any rights in this country. Otherwise, it will invite the anger of Allah, the most glorified and the most high." 43

Ustadh Abu Yahya Badrussalam, LC.

\footnotetext{
${ }^{42}$ Rodja Radio broadcast on Wednesday, 6 April 2016, from around 05.30 to $07.00 \mathrm{am}$.

${ }^{43}$ Rodja Radio broadcast on Friday, 15 January 2016, from around 17.20 to 17.40.
} 
The ustadh's answer was meant to remind the entire Indonesian Muslim society to be mindful of LGBT. Moreover, his last sentences are clearly intimidating to any Muslims who support and tolerate LGBT, especially Muslim Human Rights activists and liberal Muslims as he qualifies them as non-believers.

The next week, I listened to a question-answer session on the same issue, but this time is centered on punishment: "What is the punishment for those who love a person of the same sex?"44 The ustadh answered:

"The punishment for same sex lovers is to be thrown from a high place and
to rain stones on them as mentioned in the Quran, Hud $/ 11: 82^{45}$. Indeed, there
are various opinions regarding the way perpetrators should be punished.
Some ulama (Islamic scholars) said they should be killed while other said
they should be stoned (rajam). The Prophet said 'If you find a person who
sodomized his lover, then kill them both.' The government must implement
this punishment and nobody has the right to do in the place of government.
In the same vein, a person who makes love with a dog should be killed, both
the perpetrator and the dog, according to the Prophet. What about lesbians?
Lesbian are condemned to ta'zir r, the punishment decided upon by the
government." Ustadh Mahfudz Umri, LC.

Muslim preachers normally based their answeres on the Quranic, hadis, and fiqh norms rather than on national regulations or the international legal system. The salafi preachers' response to LGBT issues shows actually that they are strongly committed to implementing their conservative interpretation of Islam. They do so to strengthen traditional and conservative religious understanding. They aim to educate Muslim families and individuals to strongly refrain from becoming LGBT persons or even LGBT supporters.

\section{Issues on Islamic Penal Law}

Another controversial issue that I found interesting in another question-answer session is concerned with Islamic penal law. On Saturday 16 January 2016, a listener inquired about the

${ }^{44}$ Rodja Radio broadcast on Tuesday, 12 April, at about 19.25.

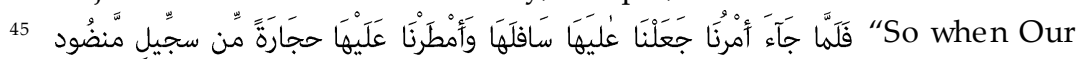
Commandment came, We turned (the town of Śodom in Pa lestine) upside down, and rained on them stones of baked clay, piled up". 
punishment for theft in Islam as he found that in Indonesian society, people would punish a thief in their own way, sometimes even leading to the thief's death. Ustadh Ahmad Ridwan, LC. replied that stealing should be punished by cutting off the hand.

In the following months, many listeners asked questions about Islamic penal law such as the example below.

Here in Indonesia, the ft is not punished by hand cutting and illegal sexual relationships (zina) a re not sentenced to de ath by stoning (rajam). What is the opinion on those who do not follow the laws of the Quran? Please give us the explanation. ${ }^{46}$

\section{The ustadh answered:}

"Your question is very good. Those who reject the principles of Islam and the teachings of the Qur'an and the hadis only follow their desires and lusts (shahwat). Here in Indonesia, the government should take responsibility against those who deviate, because of their rejection to abide to the laws of Allah. Many people declare that they are Muslims, but they do not put the laws of Allah in practice. This is one form of being astray (sesat) and for them, what matters more is the State (they are concerned only with the State). The prophet, peace be upon him, said 'you have to strictly hold on to the two pillars, then you are saved, they are the Quran and my Sunna. Accordingly, those who do not follow my Sunna are misguided."

Ustadh Ahmad Zainuddin, LC.

Apart from being astray or misguided, Radio Rodja also categorized those who reject the laws of Allah as hypocrites (munāfiq) such as in the program it aired on Friday, 15 January 2016, from around 17.20 to 17.40 .

Are there any justifiable reasons that allow us to kill a person and what are the procedures? ${ }^{47}$

Bapak Yusuf from Bekasi

"There are a mong us who have killed another person without any justifiable reason and the Prophet, peace be upon him, said that one of the rea sons why people kill others is that they did not use their common sense. Indeed, there are reasons that justify killing a person. For example, a government or a judge sentences a person to death for reasons justifie d by our religion: he/she killed another person or caused serious da mage on earth, or ma rried women who had committed adultery. According to the Prophet, peace be upon him,

\footnotetext{
${ }^{46}$ Rodja Radio broadcast on Saturday, 11 March 2016, from around 18.30 to 20.00 .

${ }^{47}$ Rodja Radio broadcast on Tuesday, 15 March 2016, from around 05.30 to 07.00.
} 
'Is not lawful to impose the death penalty except in three cases: someone who killed another person intentionally, and those who commit adultery or apostasy.' These are the reasons for which the government can impose the death penalty."

Usta dh Arman Amri, LC.

Based on the answers given by Rodja preachers, it seems that in criminal cases they want to implement Quranic penal law and follow the Tradition of the Prophet literally. Their standing on the enactment of Islamic penal law shows that they are strongly committed to implementing their conservative interpretation of Islamic law. The salafi preachers have seemingly acquired an aura of authority and legitimacy. Their rigid position and their mere citing and literally following of the Quranic law to solve social problems tells us that they are inflexible in their search for solutions suited to modern Indonesian Muslim society. Instead of calling to obey the national legal system or a more justifiable Islamic law, they preach to implement Islamic penal law as solution.

\section{Issues on Education and Technology}

Part of Salafi dakwah on Rodja Radio reveals its rejection of music or of some subjects, such as philosophy or tasawuf (Islamic spirituality and mysticism) that might be taught to students, as the following question-answer session demonstrates: What is the rule on music in Islam? ${ }^{48}$ The preacher answered:

"Music in Islam is harām (unlawful) because many negative aspects are found in music, such as enjoyment and mere killing time because of which much time is wasted. It would be better to read the Holy Quran and praise Allah, the most glorified and the most high, rather than to play the guitar."

Ustadh Jazuli, LC.

The same question was raised by a listener three days later:

What is the Islamic rule on music or singing? Is it harām to teach music or singing to students? ${ }^{49}$

Teacher from Palangka raya

\footnotetext{
${ }^{48}$ Rodja Radio broadcast on Wednesday, 23 March 2016, from around 16.30 to 18.00 . 09.00.

${ }^{49}$ Rodja Radio broadcast on Saturday, 26 March 2016,from around 08.00 to
} 


\section{The ustadh answered:}

"Everything that is forbidden in sharia is unlawful to teach to pupils and children. Harām (unla wful) remains harām and the result of something that is harām is harām. The refore, it is totally wrong to offer students something that is harām like offering them music or singing lessons. Teaching music or singing is like teaching how to sell narcotics and drugs. This is harām and do you want your children to have the skill to sell narcotics? So, you have to teach something that is good for the ir future and not teach them something that is harām."

Ustadh Kholid Syamsuddin

\section{Rodja Radio categorizes studying philosophy also as being harām:}

What is the Islamic rule on studying philosophy? What if someone takes a class on philosophy just to get a passing grade? Please explain to us. ${ }^{50}$

Abdullah from Cikarang, Bekasi.

\section{The preacher answered:}

"All Islamic scholars ('ulama) agree that studying philosophy is harām (unlawful and illegal). According to Imam Shāfi'î, the punishment for specula tive theologian and philosophers is to get beaten by a branch of the date palm. It is better to learn theology (me: according to Hanbali theology) than philosophy. In fact, philosophy can damage the mind and destruct the faith, because in philosophy to get to know Allah, the Creator, one only needs to use the mind, while the human mind is very limited. So, that is why all Muslim scholars agree that studying and learning about philosophy is harām. Just learn and study theology, not philosophy. The difference between theology and philosophy is very small; theology came after philosophy."

Ustadh Abu Yahya Badrussalam, LC.

Another interdiction in education is to study and practice tasawuf (Sufism or mysticism): What is the rule in Islam to learn about and practice tasawuf ${ }^{51}$ The preacher answered:

"Studying and practicing tasawuf (mysticism/Sufism) is harām (unlawful and illegal). Sufism could lead you to go astray and become misguided (sesat). Sufism will lead to unbelief and infidelity (kekufuran). In Sufism, you will be taught not to perform the prayers (salat) because these prayers are not obligatory in Sufism. In Sufism, you will deny and negate the ritual obligations in Islam."

Ustadh Abdullah Taslim, LC.

\footnotetext{
${ }^{50}$ Rodja Radio broadcast on Wednesday, 13 April 2016.

${ }^{51}$ Rodja Radio broadcast on Thursday, 28 Ja nuary 2016, from a round 06.45 to
} 07.15. 
Salafi dakwah on Rodja Radio is against technology since it might lead to negative things. However, Rodja Radio uses technology for its dakwah purposes, which reveals its ambivalence towards modern life.

Some questions concern the Internet and television: What is the Islamic rule on the Internet? ${ }^{52}$ The preacher answered:

"Internet is harām (unlawful and illegal) as it contains negative things such as pornography. When used to learn something good and positive, one may use the Internet, but please stay away from the Internet."

Usta dh Abdullah Zaen, MA.

What is the rule in Islam on television? ${ }^{53}$ The ustadh answered:

"Watching television is allowed but depends on the intention and the
purpose of watching it. You can watch tele vision that teaches the Sunnah.
Otherwise, it is harām. Watching television is harām and forbidden because it
shows things that are harām. According to Ibn Baz, it is unla wful to watch
television because you will watch obscene scenes. You watch women on the
television and thus it is harām."

Ustadh Abdul Hakim Abdat

Education and technology are important in daily life. The preacher's answers on Rodja Radio may be seen as unsuitable to the modern world. Rodja Radio makes no attempt to adapt Islamic doctrines and teachings to the views of the world in the $21^{\text {st }}$ century. The Salafi rejects technology such as Internet, radio, and television. However, they use them which are also technology. Can it be explained as inconsistency or is there a different degree by the Salafi in accepting and accommodating technology? I do not know. Indeed, further research needs to be done to answer such questions. In short, this shows merely the paradox of Rodja: they criticized the modern technology, but they use for their own dakwah.

${ }_{52}$ Rodja Radio broadcast on Monday, 25 January 2016, from around 08.30 09.00 .

53 Rodja Radio broadcast on Sunday, 26 June 2016, afternoon (rebroadcasted). 


\section{On Women's Issues}

Other interesting topics to look at more closely on the dakwah presented by Rodja Radio are those pertaining to women's issues such as the following: What is the rule in Islam on women going to a mall, the market, or a commercial center? ${ }^{54}$ The preacher answered:

"Women may go to the market or a mall, but not in order to engage in tabarruj (to overdress or to flaunt). If a woman goes to a market or a commercial center, she should not wear a nice dress and must not wear perfume on her clothes or on her body. In fact, the market is a place of the devil (setan). Women should not use perfume, because it will attract people. She would be like a prostitute, na'udhu billah, we ask Allah's protection."

Ustadh Abu Yahya Badrussalam, LC.

In the following days, the topic on women remained the same. The issues centered around fitna (temptation and disorder) that might create temptation and disorder in society according to the preaching of Ustadh Abu Yahya Badrussalam. ${ }^{55}$

\section{Another question was on women workers:}

I want to aska question. What is the rule in Islam on women who work as a civil servant outside their home with the intention to work for Allah and to support their families? I ask your explanation. ${ }^{56}$

Robiatul Ada wiyyah from Jakarta

\section{The preacher answered:}

"There are some justifiable reasons that allow women to have a career (to work). First, they should have the permission of their husbands. Second, they must first exe rcise and perform their roles and obligations as mothers and housewives. Third, there should not be any ikhtilath, mixing between men and women in the workplace. However, it is best for women to stay at home in order to execute herobligations as mothers and housewives, if their husbands fulfill the needs of their families. This is to safe them from fitna (temptation and disorder). Even more, women will receive much more reward (pahala) if they do their tasks and obligations at home."

Ustadh Mahfudz Umri, LC.

\section{Another question on women workers was:}

\footnotetext{
${ }^{54}$ Rodja Radio broadcast on Thursday, 4 February 2016, from around 17.00 to 17.40 .

${ }^{55}$ Rodja Radio broadcast on Friday, 12 February 2016, from around 15.00 15.45 .

56 Rodja Radio broadcast on Monday, 11 April 2016, a round 17.47.
} 
This is about a woman worker. After having gained knowledge about the Sunnah (the Salafi interpretation) and having listened to this radio station she decides to quit from her job and to dedicate herself to her husband. In the meantime, she wants to study for a BA degree and will ask her husband for the tuition fees, what is the rule in Islam for such a woman? ${ }^{57}$

A mother from CentralSulawesi

\section{The preacher answered:}

[...] First, the obligation of a wife is to serve her husband. Furthermore, the Prophet, peace be upon him, said "If it were allowed to prostrate to a human being, I would ask the wife to prostrate before her husband". The refore, if you want to seek the reward and the blessing of Allah, you have to serve and obey your husband. Second, women who work outside their homes will cause disorder and chaos (fitnah), even more so if they only work to seek worldly pleasures or to purchase this and that, etc. This is not allowed because their needs should be fulfilled by their husbands. It is not the women's task to work and to earn money. Third, a wife who wants to study should obtain her husband's consent and her study must not intrude on her obligations as a housewife. [...]

Ustadh Abu Ihsan al-Atsary

Working as a teacher is also a concern of women listeners to Rodja Radio:

What is the rule in Islam about women teachers? 58

Ummu Khatimah from Central Kalimantan.

\section{The preacher answered:}

"Based on the verse "Waqarna fìbuyūtikum..." that obliges women to stay at home, they should do so. It is better when women stay at home. It will bring about the reward and the blessing of Allah, the most glorified and the most high. However, teaching is allowed in Islam, if the teaching is about sharia issues."

Ustadh Abu Ya'la Kurnaedi, LC.

\section{One preacher gave a shocking answer:}

Usta dh, I have a daughter and she wants to work after her graduation. What is the Islamic rule for a young girl to work? ${ }^{59}$

A father from an unidentified place

\footnotetext{
${ }^{57}$ Rodja Radio broadcast on Monday, 30 May 2016, around 14.53.

58 Rodja Radio broadcast on Tuesday, 10 May 2016, from around 18.30 -

${ }^{59}$ Rodja Radio broadcast on Sunday afternoon, 26 June 2016 (direct).
} 19.00 . 


\section{The preacher answered:}

"Why you do not marry her to a good Muslim? The problem for women workers is that they become more independent because of the money they earn from their work and accordingly they do not want to take care of their children, they neglect their duties to raise their children. Therefore, it is better for women, even more so for young girls, to stay at home. This is what Allah said in the Quran (Sura al-Ahzāb/33:33): "And abide in your houses and do not display yourselves as [was] the display of the former times of ignorance". However, if she wants to work, she has to choose a job that complies with the Sunna."

Ustadh Abdul Hakim Abdat

The preacher ordered a father to marry off his daughter instead of allowing her to work or to study. He was adamant to limit women to do their domestic work without thinking of their future.

Rodja's preacher even wants to restrict women's role in dakwah:

I have two questions: what is the Islamic rule on women preachers in propa gating and disseminating Islam? And why do women inherit a smaller share of the inheritance than men? ${ }^{60}$

Abu Mizan from East Jakarta

\section{The preacher answered:}

"Talking about issue on dakwah by women, the re is in fact the basic principle of “Al-nisā'u shaqā'iq al-rijāl", النساء شقائق الرجال meaning 'women are the sisters of men.' When Allah asked people to engage in dakwah, He addressed His message (khitâab) to men. Indeed, Allah allows women preachers (women who engage in dakwah) in Islam but not to the extent of men. Women may engage in dakwah, but it should be in Islamic corridor. Dealing with your second question on the different shares of an inheritance between men and women in Islam, in fact you have no right and are not allowed to ask such question! Allah has already decided all laws in the Quran and He knows the best for His servants, because He is The All-Knowing (al-'Alim) and The Most-Judicious (al-Hakim). Obviously, Allah Himself decided in the Quran, sura al-Nisa $\bar{a}^{\prime}$, that the share of men is twice that of women ${ }^{61}$. It may seem that Allah is unjust and unfair, but He decided as such because there is wisdom behind the difference of their shares. Women in Islam are not obliged to work because that is the obligation of men."

${ }^{60}$ Rodja Radio broadcast on Tuesday, 10 May 2016, from around 18.30 to 19.00.

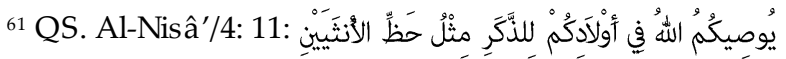


Ustadh Abu Ya la Kurnaedi, LC.

Another question I found interesting was about women's participation in politics and social-activism.

What is the rule in Islam if women participate in political life only for Allah, the most glorified and the most high? ${ }^{62}$

Lia from Jakarta

The preacher answered:

"Thank you for your question. In this era, a woman is allowed to participate
in a political movement and in a political party, but she should consider
many things. In fact, women have obligations and it has to be their priority
to execute the se obligations, such as taking care of their husbands and
children. It is mentioned that women are the leaders in managing their
husbands' houses and children. As the matter fact, the place of women is
at home and that should be their priority before doing activities outside."

Ustadh Ahmad Zainuddin, LC.

What is the rule for women activists (women who are active) in NGOs, such as NGOs or Movements thatcollect funding and donations from the people? Is it allowe din Islam? 6364

A mother from Jakarta

"It is better if women stay at home. They have to execute their obligations as house wives. They must obey their husbands. So, women should execute their tasks at home."

Ustadh Abu Ihsan Al-Atsary

The salafi preachers obviously restrict women's rights and limit their roles to domestic realms. They restrict women's participation in social and political life and even disallow them to work as teachers. Salafi preachers act as a task force to re-Islamize Indonesian women since they accuse them of being westernized which they consider immoral.

\section{Rodja and Islamic Puritanism}

The content of the Rodja Radio dakwah echoes the literal understanding of Islam and challenges the majority moderate

${ }^{62}$ Rodja Radio broadcast on Wednesday, 16 March 2016 (live) from around 10.00 to 11.00 and on Wednesday, 30 March 2016 (re-broadcasted) around 14.50.

${ }^{63}$ Rodja Radio broadcast, January 15, 2016.

${ }^{64}$ Rodja Radio broadcast on Tuesday, 31 May 2016, a round 06.00-07.00. 
Islamic perception of Indonesian Muslims. The four issues I presented above pose serious problems to Indonesian Muslim society. On the one hand, they have to struggle to enter modern life but, on the other, salafi dakwah doctrine prevents this. Salafi dakwah is extremely rigid and differs significantly from that of the majority of preachers, who are more flexible, and remain very popular among the ordinary people. However, the penetration of Indonesian society by social media has caused this salafi dakwah to gain popularity and grow rapidly among Indonesian society.

Rodja Radio repeatedly states that Muslims who do not follow the pure, rigid Prophetic tradition (Hadith and Sunna) and engage in religious innovation are idolatrous. This is even truer when we consider the answers of the salafi preachers, which, no doubt, create puritan, ultra-conservative, fundamentalist or even radical views that may promote intolerance and exclusivism among the people. The salafi preachers are strongly committed to educating and enlightening the general Muslim community who, according to them, still remains far removed from the practice of true Islam. Salafi-Wahhabi preachers urge Muslim communities to indulge in the same religious ideology of salafism. They ignore human beings' plural nature despite the clarity of the Quranic statements, such as those found in QS. 11: 118 "And if your Lord had willed, He could have made mankind one community, but they will not cease to differ;" and in QS. 10:99 "And had your Lord willed, those on earth would have believed - all of them entirely. Then, $\mathrm{O}$ Muhammad, would you compel the people in order that they become believers?" God created human beings to be different and wants them to know each other and build a better world, as mentioned in QS. 49:13 “O mankind, indeed We have created you as male and female and made you peoples and tribes that you may know one another. Indeed, the most noble of you in the sight of Allah is the most righteous of you. Indeed, Allah is Knowing and Acquainted." 65

${ }^{65}$ Interview with many Muslim listeners in Jakarta and its surroundings between February and May 2016. 


\section{Implications of Rodja Radio for Indonesian Islam}

Rodja Radio is undoubtedly one of the most influential stations that has shaped Islamic discourse in Indonesia. It is dedicated to spreading salafi doctrines and Wahabism. Supported by a group of committed, highly innovative individuals, Rodja Radio has expanded its dakwah across the whole of Indonesia through partnerships with local radio stations. The dakwah of Rodja Radio potentially cause people to develop radical and sectarian tendencies due to its strict and literal understanding of the Islamic doctrines. The number of people who subscribe to Salafi dakwah on Rodja Radio may grow, which could pose a threat to the diversity and plurality of Indonesian society. The Salafi communities have strong networks that consist of committed individuals who wish to share and disseminate puritanism thinking.

The growing number of followers of, and listeners to, the Salafi Rodja Radio has become increasingly visible because of their special forms of Islamic expression: sporting a beard, a black forehead, trousers above the ankle, and wearing a complete veil. Based on the four aforementioned issues on the dakwah materials promoted by the Salafi preachers on Rodja Radio, Salafism has given another 'color' to Indonesian Islam.

Even though no statistical data exist that prove a direct relationship between the Salafi discourse on Rodja Radio and Islamic Muslim practice, such as radicalism, the implication cannot be ignored. Moderate Indonesian Muslims are represented by two largest Islamic mass organizations Nahdlatul Ulama and Muhammadiyah. ${ }^{66}$ One example that must be mentioned here is what NU has been doing to counter this salafization of Indonesian Muslims. In other words, NU has devoted efforts to counter Salafi preaching on Rodja Radio. They implement creative programs in mosques in order to make mosque management more professional and provide with more solid counter-narrative arguments against Salafi-Wahhabi preachers. Some training programs and education for Imams (mosque managers/leaders) and religious teachers

${ }^{66}$ Muhammadiyah has many programs that promote views of peaceful and tolerant Islam, but that will be discussed separately. 
(ustaz) are organized through its program, Pelatihan Muharrik Masjid (Mosque Leaders' Training) throughout Indonesia. This program is co-organized jointly by Lembaga Takmir Masjid (LTM, Institute of Mosque Management) and Lembaga Dakwah (LD, Institute of Dakwah). Through this training, preachers (khatib), Imams, and mosque managers are taught the teachings of Ahlus Sunnah Waljamaah. This means that they learn and must loyally follow the Aqìdah (theology) of Ash'ariyyah (Abū al-Hasan alAsh 'arī, d. 324/936) and Maturidiyyah (Abū Manșūr al-Māturīdī, d. 332/944 ); the Fiqh (Islamic Law) of four schools: Hanafĩ (Imam Abū Ḥanīfa, d. 150/772), Mālikī (Imam Mālik, d. 179/795), Shāfi 'ī (Imam al-Shāfi 'î̀, d. 204/820), and Hanbali (Aḥmad ibn Ḥanbal, d. 241/855); and finally Tasawuf (Islamic Mysticism): Abū Junayd alBaghdādī (d. 298/910), al-Ghazālī (al-Ghazālī, d. 1111), and Abū alḤasan al-Shādhilī (d. 656/1258). ${ }^{67}$ Furthermore, NU's broadcasting through NU's affiliated radios (such as Radio NU, NU Radio, Radio Silaturahim, etc.) and televisions (such as TV 9 Nusantara, NU Channel, TV NU, etc.) promote moderate and tolerant Islam as a counter discourse against the Rodja Radio broadcast on Salafism.

The main contents of the syllabus of the training are based on the philosophy of Islam Nusantara that is a result of the blending and merging of Islam within Indonesian culture. In fact, the essence of Islam Nusantara is to adopt Islam as its principal source of the Truth (al-Qur'an, Hadìth, Ijmā', and Qiyās) but simultaneously to do so with respect for local cultures and values that do not conflict with Islamic teachings and doctrines. ${ }^{68}$ Islam Nusantara is an interpretation of Islam that takes into account the local Indonesian customs in forming its figh (Islamic law) or social, political and religious practices. In other words, Islam has interacted with the culture and values of Indonesia. Islam Nusantara has paved the way for turning Indonesia into a tolerant,

67 Interviews with KH. Abdul Manan Ghani on 8 March 2016, Ustadz Muhammad Husni Thamrin and Ustadz Ali Sobirin on 17 February 2016 from LTM-PBNU and KH. Manarul Hidayah on 22 January 2016, Ustadzah Afifah on 20 February 2016, Usta dz Syamsul Maa rif and Usta dz W ahid on 5 February 2016 from LD-PBNU. My research assistants conducted these interviews: Lukman Hakim al-Hadi, Nur Rahmat Farhan Jamil, and Muhammad Shofwan Nidhami. ${ }^{68}$ Ibid. 
peaceful pluralistic society, with a wide variety of languages, ethnic groups, and religions. ${ }^{69}$ Islam Nusantara, as NU's ideology, may become a bulwark against religious puritanism, fundamentalism, and even radicalism, as Salafi-Wahabi preachers tend to promote through Rodja Radio. ${ }^{70}$

This article confirms and strengthens Martin van Bruinessen's argument that, since 2005, Indonesian Islam has been witnessing what he calls a "conservative turn." Van Bruinessen wrote "the term "conservative" refers to the various currents that reject modernist, liberal or progressive re-interpretations of Islamic teachings and adhere to established doctrines and social order. Conservatives notably object to the idea of gender equality and challenges to established authority, as well as to modern hermeneutical approaches to scripture." 71 Islamic puritanism, as defended by the Indonesian Salafi-Wahhabi, clearly shows that they oppose the ideas of modernity, as I have demonstrated above. Precisely, I have shown through the responses of the Rodja's preachers that this Salafi radio station propagates a puritanical Islam way of life that contradicts the attitudes prevalent in modern life and Indonesian customs, values, traditions, and mores. Rodja Radio's preachers demonstrate their reluctance to embrace modern

${ }^{69}$ See for instance Nadirsyah Hosen, "Islam Nusantara: A Local Islam with Global Ambitions?," Indonesia at Melbourne, last modified February 25, 2016, accessed December 19, 2018, http://indone sia atmelbourne.unimelb.edu.au/islamnusantara-a-local-islam-with-global-ambitions/; Giora Eliraz, "Indonesia's Nahdlatul Ulama: A Tolerant, Inclusive Message to the Arab Middle East," Middle East Institute, last modified October 14, 2016, accessed June 19, 2018, https://www.mei.edu/publica tions/indonesias -nahdlatul-ulama-tole rantinclusive-message-arab-middle-east.

${ }^{70}$ For further analysis on how Islam Nusantara could become a counter discourse (or counter ideology?) against intolerance and radicalism, see an interesting piece by Ahmad Najib Burhani, Islam Nusantara as A Promising Response to Religious Intolerance and Radicalism, vol. 21, Trends in Southeast Asia (Singapore: ISEAS-Yusof Ishak Institute, 2018), https://www.iseas.edu. sg/images/pdf/TRS21_18.pdf.

${ }^{71}$ Martin van Bruinessen, “Contemporary Developments in Indonesian Islam and the 'Conservative Turn' of the Early Twenty-First Century, Introduction," in Contemporary Developments in Indonesian Islam: Explaining the "Conservative Turn," ed. Martin van Bruinessen (Singapore: Institute of Southe ast Asian, 2013), 16. 
ideas, such as democracy, human rights, women's rights, and, to some extent, art and education, and condemn Indonesian religious practices.

The question is that why this has happened. Van Bruinessen explained two factors that have made Indonesian Islam more conservative. First, democracy, which Indonesian gained in 1998 after the fall of Suharto, opened the gate to freedom of expression and created free public space in which to express faith, religious behavior and religious thought. ${ }^{72}$ Prior to this democratization process, pre-1998, the 'fundamentalist, radical, puritanical, and extremist' Islamic discourse (like Salafi-Wahhabi) was repressed and imprisoned by the Suharto authoritarian regime. The Suharto regime only gave voice to moderate Muslims (MUI, NU, and Muhamadiyyah). After the reformasi era, the public space became open to everyone, including the most puritanical people, like the Salafi-Wahhabi preachers on Rodja Radio, and the increasing influence of the Middle-East, mainly the Arabian peninsula, in the form of returning graduates from Saudi universities Saudi-owned and Saudi or Kuwaiti-funded educational institutions in Indonesia, sponsored translations of numerous simple "fundamentalist" texts, and ideological as well as financial support for transnational Islamic movements. ${ }^{73}$ I have explained above that the majority of Salafi-Wahhabi preachers on Rodja Radio graduated from Saudi universities (in Riyadh and Medina) or in LIPIA Jakarta. They became agencies (religious teachers and dai) for spreading the teachings and messages of the SalafiWahhabi-Saudi version of Islam.

As was correctly pointed out by Khaled Abou El Fadl, these Muslim puritans always "accuse moderates of having changed and reformed Islam to the point of diluting and corrupting it. And moderates accuse the puritans of miscomprehending and misapplying Islam to the pint of undermining and even defiling the religion." ${ }^{74}$ However, on certain issues, they are inconsistent in their preaching. They condemn the use of technology, such as

\footnotetext{
72 Ibid., 5.

${ }^{73}$ Ibid.

${ }^{74}$ Abou El Fadl, The Great Theft, 5.
} 
radio, television, and the internet, but use them for their own dakwah purposes. It is also important to note that even among the Salafi Rodja Radio's preachers; they do not have a common answer. For instance, regarding their opinion of women's work, one preacher's view is more flexible, while another's is very strict. They respond to the question differently. In general, dakwah on Salafi Rodja Radio on women fosters teaching and doctrines that are not 'friendly' to women. Salafi preachers have been spreading authoritarian, ultra-conservative, purist and fundamentalist ideas on Islamic doctrine.

\section{Conclusion}

In the rapidly-growing urbanized Indonesian society, Rodja Radio has played an important role in building the Salafi identity that is faithful to the Tradition of the Prophet. This radio station strengthens forms of religious behavior and practice that in many respects fail to match the views of modern times. The SalafiWahhabi have a problem with modern issues, such as women's rights, technology, the national legal system and other things, and raise a variety of Islamic discourses on radio in a strict manner. They are inflexible in their preaching and tend to create intolerant, exclusive people. The issue is that the salafization of Indonesian Islam could pose a threat to the country through their 'brutal' criticism of the religious practices of Indonesian Muslims.

There might be a growing number of listeners to Rodja Radio, yet still only a few Indonesian Muslims adhere to the preaching of Salafism. I do not have an exact number of Salafi adherents, but this group is still (a very vocal) minority amidst of moderate Indonesian Islam. Even though the Salafi use the radio, which is a public sphere, to disseminate the message of 'Islamic Puritanism' in Indonesia, their dakwah is not very welcome among Indonesian Muslims in general. This is due to the rigidity and strictness of their dakwah. Moreover, Moderate Indonesian Islam, represented by NU (and Muhamadiyyah), as I explained above, has a strong network and basis in the Muslims' grassroots, which enables them to construct a counter-narrative to the Islamic discourse that is being disseminated by the Salafi-Wahhabi preachers via Rodja Radio. This is because, according to Robert Hefner, "Civil Islam" is 
prevailing in Indonesian Islam. This 'Civil Islam' is the Indonesian Islam version that "emerged in the 1980s and 1990s a democratic, religiously ecumenical, and boldly reformist movement that promote women's rights, inter-religious dialogue, and the struggle to create a democratic and pluralist polity."75 The majority of Indonesian Muslims constantly promotes and strives to implement Moderate Islam and this 'Civil Islam' in Indonesia, despite the worrying rise of Islamic puritanism that may make Indonesian Islam more conservative.

\section{References}

Abou El Fadl, Khaled. Reasoning with God:Reclaiming Shari'ah in the Modern Age. Lanham-London: Rowman \& Littlefield, 2017. - - - The Great Theft: Wrestling Islam from the Extremists. New York: HarperCollins, 2007.

Adeni. "Institusi Televisi Keislaman: Studi atas Rodja TV sebagai Media Islam Salafi." Master Thesis, Universitas Islam Negeri Syarif Hidayatullah, 2016.

Aminah, Siti. “Strategi Informasi Konvergensi Media: Studi Kasus

Radio Rodja 756 AM, Cileungsi, Bogor." Master Thesis,

Universitas Islam Negeri Syarif Hidayatullah, 2014.

Bonnefoy, Laurent. Salafism in Yemen: Transnationalism and Religious Identity. London: Hurst, 2011.

Bowen, John R. "Beyond Migration: Islam as a Transnational Public Space." Journal of Ethnic and Migration Studies 30, no. 5

(September 1, 2004): 879-894. https://doi.org/10.1080/ 1369183042000245598.

van Bruinessen, Martin. "Contemporary Developments in Indonesian Islam and the 'Conservative Turn' of the Early Twenty-First Century, Introduction." In Contemporary Developments in Indonesian Islam: Explaining the "Conservative Turn," edited by Martin van Bruinessen, 1-20. Singapore: Institute of Southeast Asian, 2013.

Burhani, Ahmad Najib. Islam Nusantara as A Promising Response to Religious Intolerance and Radicalism. Vol. 21. Trends in

75 Robert W. Hefner, Civil Islam: Muslims and Democratization in Indonesia (Princeton: Princeton University Press, 2000), i-xx, xvii-xviii. 
Southeast Asia. Singapore: ISEAS-Yusof Ishak Institute, 2018. https://www.iseas.edu.sg/images/pdf/TRS21_18.pdf.

Delong-Bas, Natana J. Wahhabi Islam: From Revival and Reform to Global Jihad. Oxford: Oxford University Press, 2004.

Duderija, Adis. "The Regress of Knowledge: Understanding the Concept of Salafism in Traditional Sunnism." ABC Religion $\mathcal{E}$ Ethics. Last modified January 12, 2017. https://www.abc.net. au/religion/the-regress-of-knowledge-understanding-theconcept-of-salafism-i/10096166.

Egerton, Frazer. Jihad in the West: The Rise of Militant Salafism. Cambridge: Cambridge University Press, 2011.

Eliraz, Giora. "Indonesia's Nahdlatul Ulama: A Tolerant, Inclusive Message to the Arab Middle East." Middle East Institute. Last modified October 14, 2016. Accessed June 19, 2018. https://www.mei.edu/publications/indonesias-nahdlatululama-tolerant-inclusive-message-arab-middle-east.

Gauvain, Richard. Salafi Ritual Purity: In the Presence of God. London: Routledge, 2013.

Habermas, Jurgen. The Structural Transformation of the Public Sphere: An Inquiry into a Category of Bourgeois Society. Translated by Thomas Burger. Cambridge: The MIT Press, 1989.

Hefner, Robert W. Civil Islam: Muslims and Democratization in Indonesia. Princeton: Princeton University Press, 2000.

Hoasterey, James B. James B. Hoasterey, Rebranding Islam: Piety, Properity, and a Self-Help Guru. Standford: Standford University Press, 2015.

Hosen, Nadirsyah. "Islam Nusantara: A Local Islam with Global Ambitions?" Indonesia at Melbourne. Last modified February 25, 2016. Accessed December 19, 2018. http://Indonesia atmelbourne.unimelb.edu.au/islam-nusantara-a-local-islamwith-global-ambitions/.

Howell, Julia Day. "Modulations of Active Piety: Professors and Televangelists as Promoters of Indonesian 'Sufisme.'" In Expressing Islam: Religious Life and Politics in Indonesia, edited by Greg Fealy and Sally White, 40-62. Singapore: ISEAS Publishing, 2008.

Jahroni, Jajang. "The Political Economy of Knowledge: Shari ah and Saudi Scholarship in Indonesia." Journal of Indonesian Islam 
7, no. 1 (June 1, 2013): 165-186. Accessed December 19, 2018. http://jiis.uinsby.ac.id/index.php/JIIs/article/view/124.

Kovacs, Amanda. "Saudi Arabia Exporting Salafi Education and Radicalizing Indonesia's Muslims." GIGA Focus International Edition English, no. 07 (2014). https://www.giga-hamburg. de/en/publication/saudi-arabia-exporting-salafi-educationand-radicalizing-indonesia $\%$ E2\%80\%99s-muslims.

Lauziere, Henri. The Making of Salafism: Islamic Reform in the Twentieth Century. New York: Columbia University Press, 2016.

Mendieta, Eduardo, and Jonathan Vanantwerpen. The Power of Religion in the Public Sphere. New York: Columbia University Press, 2011.

Pall, Zoltan. Kuwaiti Salafism and Its Growing Influence in the Levant.

Washington: Carnegie Endowment for International Peace, 2014. JSTOR. https://www.jstor.org/stable/resrep12899.

- - - Lebanese Salafis between the Gulf and Europe: Development, Fractionalization and Transnational Networks of Salafism in Lebanon. Amsterdam: Amsterdam University Press, 2013. https://www.jstor.org/stable/j.ctt46n0kn.

- - - Salafism in Lebanon: Local and Transnational Movements. Cambridge: Cambridge University Press, 2018.

Rodja Radio broadcast, January 15, 2016.

Roel, Meijer, ed. Global Salafism: Islam's New Religious Movement. London: Hurst, 2009.

Rougier, Bernard. Qu'est-Ce Que Le Salafisme? Paris: Presses Universitaires de France, n.d.

Simpson, J A, and E S C Weiner. New Oxford Dictionary of English. Oxford: Oxford University Press, 1998.

Sofjan, Dicky, and Mega Hidayati. Religion and Television in Indonesia: Ethics Surrounding Dakwahtainment. Geneva: Globethics.net, 2013.

Suharto, Toto. "Transnational Islamic Education in Indonesia: An Ideological Perspective." Contemporary Islam 12, no. 2 (July 1, 2018): 101-122. https://doi.org/10.1007/s11562-017-0409-3.

Sunarwoto. "Contesting Religious Authority: A Study on Dakwah Radio in Surakarta, Indonesia." Doctoral Thesis, Tilburg University, 2015. 
- - - "Salafi Dakwah Radio: A Contest for Religious Authority." Archipel.Études interdisciplinaires sur le monde insulindien, no. 91 (May 15, 2016): 203-230. Accessed December 21, 2018. http://journals.openedition.org/archipel/314.

Wagemakers, Joas. "Salafism." Oxford Research Encyclopedia of Religion (August 5, 2016). Accessed March 19, 2018. http://oxfordre.com/view/10.1093/acrefore/9780199340378.001. 0001/acrefore-9780199340378-e-255.

Wahid, Din. "Nurturing the Salafi Manhaj: A Study of Three Salafi Pesantrens in Contemporary Indonesia." PhD Thesis, Utrech University, 2014.

Wahid, Din, and Jamhari Makruf, eds. Suara Salafisme Radio Dakwah di Indonesia. Jakarta: Kencana, 2017.

"Puritan." Oxford Dictionaries. Accessed June 19, 2018. https://en.oxforddictionaries.com/definition/puritan.

"Puritanism." Oxford Dictionaries. Accessed June 19, 2018. https://en.oxforddictionaries.com/definition/puritanism.

\section{Interview}

Interview with KH. Manarul Hidayah on 22 ${ }^{\text {nd }}$ January 2016, Interview with Ustadh Abu Yahya Badrussalam on Thursday, around June-August 2016.

Interview with Ustadh Ali Sobirin on 17 th February 2016

Interview with Ustadh Dian Sudiana Fawwaz on Wednesday, 29 June 2016.

Interview with Ustadh Muhammad Husni Thamrin on $17^{\text {th }}$ February 2016

Interview with Ustadh Muhammad Ihsan on Thursday, 29 July 2016.

Interview with Ustadh Syamsul Maarif on $5^{\text {th }}$ February 2016.

Interview with Ustadh Wahid on $5^{\text {th }}$ February 2016.

Interview with Ustadhah Afifah on $20^{\text {th }}$ February 2016,

Interviews with KH. Abdul Manan Ghani on $8^{\text {th }}$ March 2016,

\section{Radio}

Rodja Radio broadcast on on Friday, 15 January 2016, from around 17.20 to 17.40 .

Rodja Radio broadcast on Saturday, 16 January 2016. 
Rodja Radio broadcast on Monday, 25 January 2016, from around 08.30 - 09.00.

Rodja Radio broadcast on Thursday, 28 January 2016, from around 06.45 to 07.15 .

Rodja Radio broadcast on Thursday, 4 February 2016, from around 17.00 to 17.40 .

Rodja Radio broadcast on Friday, 12 February 2016, from around $15.00-15.45$.

Rodja Radio broadcast on Saturday, 11 March 2016, from around 18.30 to 20.00 .

Rodja Radio broadcast on Tuesday, 15 March 2016, from around 05.30 to 07.00 .

Rodja Radio broadcast on Wednesday, 16 March 2016 (live) from around 10.00 to 11.00 and on Wednesday, 30 March 2016 (rebroadcasted) around 14.50 .

Rodja Radio broadcast on Wednesday, 23 March 2016, from around 16.30 to 18.00 .

Rodja Radio broadcast on Saturday, 26 March 2016, from around 08.00 to 09.00 .

Rodja Radio broadcast on Wednesday, 6 April 2016, from around 05.30 to $07.00 \mathrm{am}$.

Rodja Radio broadcast on Monday, 11 April 2016, around 17.47.

Rodja Radio broadcast on Tuesday, 12 April, at about 19.25.

Rodja Radio broadcast on Wednesday, 13 April 2016.

Rodja Radio broadcast on Tuesday, 10 May 2016, from around 18.30 to 19.00 .

Rodja Radio broadcast on Monday, 30 May 2016, around 14.53.

Rodja Radio broadcast on Tuesday, 31 May 2016, around 06.0007.00.

Rodja Radio broadcast on Sunday, 26 June 2016, afternoon (rebroadcasted).

Rodja Radio broadcast on Sunday, 26 June 2016, afternoon (direct). 